\title{
Memahami Komunikasi Antar Pribadi Dalam Pernikahan Beda Agama Dalam Upaya Mempertahankan Hubungan Yang Harmonis.
}

\author{
Indahyani \\ (indahyani59@gmail.com) \\ (Alumni Jurusan Ilmu Komunikasi Universitas Semarang)
}

\begin{abstract}
Interfaith marriage is a form of marriage is performed by a pair of men and women who have different religious beliefs. Currently interfaith marriage is already banned by the government and the logic, in the se-religious marriages can be conflict and does not guarantee a successful marriage, let alone a different religion. Although conflict in marriage is not only caused by differences in belief, but it is very influential for the survival of marriage as the basis of different faiths will make all the difference. Although it is not easy to maintain interfaith marriage, but not a few marriages that last a long time despite the different religions. Effective communication will minimize the occurrence of conflict, so the marriage will last a long time. This study seeks to examine more deeply the Self Disclosure (Self Disclosure) In Johari Window Theory, Theory of Dialectical relations (Relational Dialectics), and symbolic interactionism (symbolic Interactionism). Further in-depth interviews with select speakers who have certain criteria as research subjects, by using descriptive qualitative research methods. Presentation of data is done as it is delivered in accordance informants as research subjects without manipulation. Then, the researchers interpret the data to describe the phenomenon that occurs in study subjects.
\end{abstract}

Kata Kunci : Komunikasi antar pribadi, pernikahan, beda agama

\section{Pendahuluan}

Berdasarkan pengalaman Peneliti berinteraksi dengan pasangan-pasangan yang berbeda agama, mereka mengakui bahwa konflik memicu perpecahan. Menurut mereka, salah satu konflik tersebut misalnya penentuan agama pada anak dan dua kemungkinan yang terjadi di dalam pernikahan beda agama yaitu salah satu ikut agama pasangannya atau tetap memeluk agama masing-masing, tetapi tidak semua pasangan yang berbeda agama bisa menerima keadaan pasangannya dengan apa adanya. Oleh sebab itu, Peneliti sangat tertarik untuk meneliti lebih lanjut mengenai komunikasi antar pribadi pada pasangan pernikahan beda agama dalam upaya mencapai hubungan yang harmonis. Saat ini pernikahan beda agama sudah dilarang oleh pemerintah dan secara logika, di dalam pernikahan yang se-agama pun bisa muncul konflik dan tidak menjamin suksesnya pernikahan, apalagi yang berbeda agama. Sehingga kasus tersebut menjadi unik dan penting untuk diteliti. Pembatasan masalah dalam penelitian ini adalah dua orang yang memutuskan untuk mengikat tali pernikahan meskipun masing-masing berbeda agama yang sampai saat ini hubungannya masih langgeng dan harmonis, serta pasangan pernikahan beda agama yang sudah bercerai.

Perkawinan merupakan wujud menyatunya dua sejoli ke dalam satu tujuan yang sama, dan salah satu tujuan perkawinan adalah mencapai kebahagiaan yang langgeng bersama pasangan hidup (http://id.shvoong.com/humanities/165376 2-10-kunci-perkawinan-bahagia/). 
Sementara itu, "Dalam ajaran Islam wanita tidak boleh menikah dengan lakilaki yang tidak beragama Islam (Al Baqarah [2]: 221)." Sedangkan, dalam pandangan islam dalam keputusan Fatwa Majelis Ulama Indonesia (MUI) berNomor : 4/MUNAS VII/MUI/8/2005 tentang perkawinan beda agama telah menetapkan fatwa larangan pernikahan berbeda agama dengan alasan karena kerusakan yang ditimbulkan dari pernikahan lintas agama itu lebih besar dari pada kebaikan yang dipetiknya, terutama bagi kaum muslimin.

Sementara dalam Hukum Gereja Katolik (c.1086, 1142) Perkawinan beda agama tidaklah sah, kecuali ada ijin uskup dan jika nantinya pernikahan tersebut menghasilkan keturunan, maka keturunan atau anak harus dididik secara katolik. Alasan gereja Katolik, bukan karena pihak lain itu kafir dan akan membawamu ke neraka, tetapi karena perbedaan paham mengenai dua hal, cinta dan perkawinan. Sedangkan dalam ajaran Kristen, perkawinan beda agama juga dilarang (II Korintus 6: 14-18).

Fakta membuktikan bahwa keharmonisan hubungan keluarga dapat menjadi benteng yang kokoh bagi setiap anggotanya dalam menghadapi berbagai masalah yang datang secara tak terduga. Faktor tersebut bahkan dapat dijadikan sebagai sarana pendukung bagi para anggota keluarga dalam menyelesaikan masalah mereka dengan cara yang sebaikbaiknya. memperkokoh keluarga. Salah satu cara yang sangat efektif untuk menjaga agar keluarga tetap kokoh, salah satunya adalah dengan menerapkan nilainilai spiritual dan etis dalam keluarga.

Meskipun konflik dalam suatu pernikahan tidak hanya disebabkan oleh perbedaan keyakinan, akan tetapi hal ini sangat berpengaruh bagi kelangsungan perkawinan karena dasar keyakinan yang berbeda akan membuat segalanya berbeda. Meskipun tidak mudah dalam mempertahankan pernikahan beda agama, namun tidak sedikit pula pernikahan yang bertahan lama meskipun berbeda agama. Dengan komunikasi yang efektif akan meminimalkan terjadinya konflik sehingga pernikahan akan bertahan lama. Dalam hubungan pernikahan tercipta komunikasi antarpribadi (interpersonal communication) yaitu komunikasi antara orang-orang secara tatap muka, yang memungkinkan setiap pesertanya menangkap reaksi orang lain atau pasangan secara langsung, baik secara verbal atau non-verbal. Bentuk khusus dari komunikasi antarpribadi adalah komunikasi diadik (dyadic communication) yang melibatkan hanya dua orang, seperti suami-istri, dua sejawat, dua sahabat dekat, guru-murid dan sebagainya (Mulyana, 2004:73).

Seiring berjalannya waktu, komunikasi antar pribadi mempengaruhi jalinan hubungan. Jika komunikasi antar pribadi terjalin baik, maka akan terjadi jalinan hubungan yang semakin akrab dan harmonis, dengan adanya saling menghargai dan memberikan perhatian antara satu sama lain (http://komunikasiantarpribadi.org/2010/1 0/jalinan-hubungan-kap).

Komunikasi antar pribadi tidak hanya digunakan untuk memulai suatu hubungan baru dengan orang lain, tetapi juga untuk mempertahankan hubungan baik yang telah terjalin, serta mengatasi dan menyelesaikan konflik yang dapat mengancam suatu hubungan yang telah berjalan dengan harmonis (http://en.wikipedia.org/wiki/kap-

hubungan-harmonis/).

Seperti yang telah disebutkan sebelumnya, bahwa komunikasi antar pribadi mempunyai berbagai manfaat dalam menjalin hubungan yang lebih baik dan bermakna, hal tersebut dapat dilihat di dalam hubungan suami istri beda agama. Di awal pernikahan, masing-masing belum bisa sepenuhnya bersikap terbuka 
terhadap pasangan dan ada sebagian yang masih ditutup-tutupi. Tetapi setelah berjalannya waktu, melalui komunikasi antar pribadi akhirnya pasangan tersebut dengan sendirinya bersikap terbuka satu sama lain.

\section{Tinjauan Pustaka}

\section{Komunikasi Antar Pribadi} Komunikasi antarpribadi (interpersonal communication) yaitu komunikasi antara orang-orang secara tatap muka, yang memungkinkan setiap pesertanya menangkap reaksi orang lain atau pasangan secara langsung, baik secara verbal atau non-verbal. Bentuk khusus dari komunikasi antarpribadi adalah komunikasi diadik (dyadic communication) yang melibatkan hanya dua orang, seperti suami-istri, dua sejawat, dua sahabat dekat, guru-murid dan sebagainya (Mulyana, 2004:73).

\section{Keterbukaan Diri (Self Disclosure) Dalam Johari Window Theory}

Teori utama yang digunakan dalam penelitian ini adalah Johari Window Theory atau biasa dikenal dengan Teori Jendela Johari. Dalam Johari Window diungkapkan tingkat keterbukaan dan tingkat kesadaran tentang diri kita. Pengetahuan tentang diri akan meningkatkan komunikasi, dan pada saat yang sama, berkomunikasi dengan orang lain meningkatkan pengetahuan tentang diri kita. Dengan membuka diri, pengetahuan tentang diri menjadi lebih dekat dengan kenyataan (Rakhmat, 2001: 107).

Keterbukaan diri adalah hal yang penting untuk mewujudkan komunikasi antar pribadi yang efektif dalam upaya mencapai hubungan yang lebih akrab dan harmonis. Keterbukaan diri (self disclosure) dapat diartikan sebagai proses pemberian atau pengungkapan informasi tentang diri sendiri kepada orang lain, yang mencakup berbagai hal, seperti pikiran, perasaan, dan perilaku seseorang atau orang lain yang sangat dipikirkannya (Devito, 1997: 62). Melalui penelitian ini, Peneliti ingin mencoba menggali dan memahami pengalaman pasangan suami istri beda agama dalam berkomunikasi antar pribadi dengan adanya keterbukaan diri, dan memaknai keterbukaan diri tersebut sebagai suatu cara untuk mengatasi ketidakpastian (hambatan/konflik) dalam proses komunikasi antar pribadi pasangan suami istri beda agama sebagai upaya mencapai hubungan yang harmonis di dalam keluar

\section{Teori Dialektis dalam hubungan (Relational Dialectics)}

Teori ini digunakan untuk meneliti cara-cara yang kompleks di mana orang yang memiliki hubungan, dalam hal ini pasangan suami istri beda agama menggunakan komunikasi untuk mengatasi kekuatan yang bertentangan secara alami yang menimpa hubungan mereka setiap saat. Pemikiran tentang hubungan sebagai proses dialektis dan dialogis ini didasarkan pada langkah besar dalam Teori Dialogis Bakhtin dan Teori Baxter tentang Hubungan.

\section{Teori Dialogis Bakhtin}

Menurut Bakhtin, kehidupan di dunia sebagai salah satu kegiatan dan kreatifitas konstan serta sebagai titik awal untuk segala macam perubahan. Perubahan ini terjadi sangat lambat, hingga tidak dapat diamati dan akhirnya terjadi tindakan. Hal ini merupakan alasan mengapa keputusan-keputusan penting dibuat. Dalam hal ini, misalnya keputusan dalam hal agama bagi anak-anak di dalam perkawinan beda agama. Apakah anak diberi hak sepenuhnya untuk memilih agama yang akan mereka anut, atau justru anak dipaksa harus mengikuti agama yang sama dari salah satu orang tuanya. Bakhtin juga menyatakan bahwa 
kehidupan sehari-hari membutuhkan usaha konstan untuk menyatukan kembali kekuatan-kekuatan yang berbeda karena hal ini merupakan kewajiban dan tanggung jawab yang harus diselesaikan dari setiap situasi atau permasalahan yang hadir. Dialog adalah sebuah jaringan hubungan dengan orang lain yang kompleks (Littlejohn, 2009 : 298-301).

\section{Teori Baxter tentang Hubungan}

Baxter mengartikan bahwa hubungan merupakan sebuah tempat yang menangani pertentangan dan hubungan dihasilkan melalui dialog. Dalam pandangan pertama Teori Baxter, dalam dialoglah kita mendefinisikan hubungan kita dengan orang lain, dan hubungan terbentuk dalam pembicaraan yang terjadi dalam beberapa cara. Dalam hal ini, pasangan suami istri beda agama menciptakan momentum dan menceritakan pengalaman bersama dengan pasangan. Pada saat yang sama, pasangan suami istri tersebut saling mengenali perbedaan. Pandangan kedua dari Baxter adalah bahwa "Dialog menghasilkan sebuah kesempatan untuk mencapai sebuah persatuan dalam perbedaan. Melalui dialog, kita mengatur dinamika pengaruh antara kekuatan sentripetal dan sentrifugal yaitu kekuatan yang memisahkan dan menarik kita bersama-sama, kekuatan yang menciptakan pemahaman akan kekacauan dan kekuatan yang memberikan rasa kebersamaan."

Pandangan ketiga Baxter adalah stabilitas perubahan dan tekanan antara dapat diduga dan konsisten melawan spontan dan berbeda. Dalam pernikahan beda agama, kerap kali pasangan mengalami kebingungan antara apakah mereka harus melakukan hal yang selalu sama atau mencoba hal-hal baru dan ketika hal ini terjadi, mereka merasakan pertentangan ini. Bagaimana pasangan suami istri beda agama berinteraksi dengan tetap membiarkan beberapa hal dapat diduga dan stabil, sementara mereka juga membiarkan hubungan untuk berubah dan tumbuh. Pandangan Baxter keempat mengacu pada gagasan bahwa perilaku dan estetika (melibatkan pemahaman akan kesimbangan, keterkaitan, bentuk, dan kesatuan) bukanlah sesuau yang langsung ada, tetapi diciptakan atau dibuat dalam komunikasi. Baxter menjelaskan bahwa "Hubungan tidak pernah berupa serangkaian pernyataan orang tunggal, tetapi terdiri atas proses maju mundur yang berjalan seiring waktu" (Littlejohn, 2009:306).

\section{Interaksionisme Simbolis (Simbolic Interactionism)}

Teori ini menjelaskan proses dimana diri sendiri dikembangkan. Interaksionisme simbolis, sebuah pergerakan dalam sosiologi, berfokus pada cara-cara manusia membentuk makna dan susunan dalam masyarakat melalui percakapan. Teori ini berfokus pada interaksionisme simbolis klasik, gagasan-gagasan dasar dari gerakan tersebut dan perluasan yang secara teori harus diakui dalam bidang komunikasi. Tiga konsep utama dalam teori Mead ditangkap dalam judul karyanya yang paling terkenal, yaitu masyarakat, diri sendiri, dan pikiran. Kategori-kategori ini merupakan aspek-aspek yang berbeda dari proses umum yang sama yang disebut tindak sosial, yang merupakan sebuah kesatuan tingkah laku yang tidak dapat dianalisis ke dalam bagian-bagian tertentu. Bentuk tindak sosial paling mendasar melibatkan tiga bagian: gerak tubuh awal dari salah satu individu, respons dari orang lain terhadap gerak tubuh tersebut, dan sebuah hasil. Hasilnya adalah arti tindakan tersebut bagi pelaku komunikasi.

Tindakan bersama (joint action) antara dua orang atau lebih, seperti yang terjadi dalam pernikahan, perdagangan, 
atau perang terdiri atas sebuah interhubungan (interlinkage) dari interaksi-interaksi yang lebih kecil. Manusia menggunakan simbol-simbol yang berbeda untuk menamai objek. Objek menjadi objek melalui proses pemikiran simbolis kita; ketika kita membayangkan tindakan yang baru atau yang berbeda terhadap sebuah objek, objek itu sendiri berubah karena kita melihatnya melalui sudut pandang yang berbeda. Bagi Blumer, yang diikuti oleh Mead dalam pengembangan karya ini, objek terbagi dalam tiga jenis yaitu fisik (benda-benda), sosial (manusia), dan abstrak (gagasan-gagasan). Manusia mendefinisikan objek secara berbeda, bergantung pada bagaimana mereka bertindak terhadap objek tersebut. Jenis objek kedua menurut Blumer adalah apa yang ia sebut dengan sosial. "Interaksionisme simbolis sebagai sebuah gerakan, ada untuk meneliti cara-cara manusia berkomunikasi, memusat, atau dapat membagi makna" (Littlejohn, 2009:231). Dalam hal ini, Interaksionisme simbolis digunakan untuk meneliti caracara pasangan suami istri beda agama dalam berkomunikasi untuk mempertahankan hubungan yang harmonis.

\section{A. Metodologi Penelitian}

\section{Bentuk dan Strategi Penelitian}

Penelitian ini dilakukan dengan menggunakan metode penelitian deskriptif kualitatif. Jenis penelitian deskriptif kualitatif berupa kata-kata tertulis maupun lisan dari orang-orang dan perilaku yang diamati. Selanjutnya, penyajian data sesuai yang disampaikan informan sebagai subyek penelitian tanpa melakukan manipulasi. Selanjutnya, peneliti menginterpretasi data untuK menggambarkan fenomena yang terjadi pada subyek penelitian." (Nana Syaodih Sukmadinata, 2008: 126).

\section{Data dan Sumber Data}

Dalam penelitian ini, Peneliti mengandalkan sumber data primer dan sekunder. Sumber data primer diperoleh melalui wawancara mendalam. Sedangkan, data sekunder diperoleh melalui studi kepustakaan, dengan cara membaca buku atau mencari literatur dari sumber lain yang bersangkutan dengan permasalahan penelitian ini, misalnya seperti data yang diperoleh dari internet.

\section{Teknik Sampling}

Penelitian ini menggunakan teknik purposive sampling, yaitu teknik pengambilan sampel sumber data dengan pertimbangan tertentu. Peneliti memilih informan sebagai subyek penelitian dalam penelitian ini karena informan tersebut dianggap memenuhi kriteria dan memiliki informasi yang diperlukan bagi peneliti.

\section{Teknik Pengumpulan Data}

Pengumpulan data dilakukan dengan terjun ke lapangan. Teknik pengumpulan data lebih banyak pada observasi berperan serta (participan observation), yaitu Peneliti bertindak sebagai pengamat yang berperan aktif dengan observasi langsung ke lokasi penelitian, wawancara mendalam (indepth interiview), dan dokumentasi. Data primer akan diperoleh peneliti dari kegiatan wawancara mendalam (indepth interview) dengan informan sebagai subyek penelitian ini. Selain wawancara peneliti juga melakukan studi kepustakaan sebagai data sekunder, yaitu pengumpulan data dan informasi yang berasal dari berbagai sumber tertulis, baik dengan cara membaca atau memanfaatkan buku maupun literatur lainnya seperti surat kabar, majalah, internet, dan sebagainya. 


\section{Validitas Data}

Dalam penelitian ini, untuk menjamin validitas data digunakan triangulasi data atau triangulasi sumber, yaitu teknik pemeriksaan keabsahan data dengan memanfaatkan sesuatu yang lain di luar data. Triangulasi data bertujuan untuk keperluan pengecekan atau sebagai bahan pembanding terhadap data tersebut.

\section{Teknik Analisis Data}

Analisis data adalah upaya untuk mencari dan menata secara sistematis catatan hasil wawancara, studi kepustakaan dan lainnya untuk meningkatkan pemahaman peneliti tentang kasus yang diteliti serta menyajikannya sebagai temuan bagi orang lain. Sementara itu untuk meningkatkan pemahaman tersebut, analisis perlu dilanjutkan dengan upaya mencari interpretasi atau makna (meaning). Oleh karena itu, teknik analisis datanya berupa deskriptif kualitatif, yaitu suatu penelitian yang tidak dimaksudkan untuk menguji hipotesis berdasarkan teori-teori tertentu. Data yang diperoleh dan dikumpulkan dari berbagai sumber kemudian ditelaah dalam upaya meningkatkan pemahaman terhadap permasalahan yang diteliti. Analisis data dilakukan dalam suatu proses yang berarti pelaksanaan sudah dilakukan sejak pengumpulan data yang dikerjakan secara intensif dan interaktif.

\section{Hasil Penelitian}

Memahami komunikasi antar pribadi dalam pernikahan beda agama dalam upaya mempertahankan hubungan yang harmonis.

Temuan khas dalam penelitian ini adalah pasangan pernikahan beda agama yang bercerai ternyata mengaku bahwa mereka menyesal dan tidak akan mengulangi lagi. Sedangkan, pasangan pernikahan beda agama yang masih langgeng mengaku bahwa mereka bahagia dan tidak pernah menyesal karena telah melakukan pernikahan beda agama. Selain itu, hasil penelitian ini menguatkan tiga teori yang digunakan dalam penelitian ini, antara lain:

\section{Keterbukaan Diri (Self Disclosure)} Dalam Johari Window Theory. Keterbukaan diri dalam komunikasi antar pribadi tidak hanya digunakan untuk memulai suatu hubungan baru dengan orang lain, tetapi juga untuk mempertahankan hubungan baik yang telah terjalin, serta mengatasi dan menyelesaikan konflik yang dapat mengancam suatu hubungan yang telah berjalan dengan harmonis. Tidak dapat dipungkiri, dengan adanya perbedaan prinsip dan sudut pandang di dalam pernikahan beda agama dapat menimbulkan kesalahpahaman yang bisa saja menyebabkan ketegangan dan menimbulkan konflik antar pribadi, seperti yang terjadi di dalam pernikahan pasangan informan II yaitu Yulius Indrawan dan Ema Setiawati (pasangan yang telah cerai). Kurangnya komunikasi di antara mereka, ternyata menjadi salah satu faktor penyebab munculnya konflik di dalam pernikahan mereka. Berbeda dengan pasangan informan II yaitu Yohanes Sihana dan Yuni (pasangan yang masih langgeng) yang mengaku bahwa mereka menjaga keharmonisan pernikahan dengan saling terbuka dan mereka senantiasa mengkomunikasikan segala hal yang terjadi agar tidak terjadi kesalahpahaman yang dapat menyebabkan konflik.

2. Teori Dialektis dalam hubungan (Relational Dialectics) dari Bakhtin dan Baxter. Dalam hal ini, misalnya keputusan dalam hal agama bagi anak-anak di dalam perkawinan beda agama. Apakah anak diberi hak sepenuhnya untuk memilih agama yang akan mereka anut, atau justru anak dipaksa harus mengikuti agama yang sama dari salah satu orang 
tuanya. Penelitian ini juga membuktikan kebenaran tentang pandangan "Dialog menghasilkan sebuah kesempatan untuk mencapai sebuah persatuan dalam perbedaan." Dalam hal ini, pasangan informan I (langgeng) yaitu Yohanes dan Yuni telah sepakat untuk memberi kebebabasan sepenuhnya kepada masing-masing anak mereka dalam memilih agama yang akan dianut. Kesepakatan yang telah dicapai tentunya dihasilkan melalui suatu dialog yang terus menerus yang dilakukan oleh pasangan tersebut. Hal tersebut penting dibicarakan di awal pernikahan agar karena jika tidak, hal tersebut akan menyebabkan suatu konflik yang besar seperti yang terjadi dalam pernikahan pasangan informan II (telah bercerai) yaitu Yulius dan Ema. Ternyata selain karena kurangnya komunikasi, penyebab konflik yang lain adalah Ema yang telah memaksakan agar anaknya mengikuti agama yang dianut Ema yaitu Islam. Dalam hal ini, anak mereka lah yang menjadi korban.

3. Interaksionisme Simbolis (Simbolic Interactionism) dari Barbara Ballis Lal yang menyatakan bahwa "Interaksionisme simbolis sebagai sebuah gerakan, ada untuk meneliti cara-cara manusia berkomunikasi, memusat, atau dapat membagi makna" (Littlejohn, 2009:231). Dalam hal ini, Interaksionisme simbolis digunakan untuk meneliti cara-cara pasangan suami istri beda agama pasangan informan I dalam berkomunikasi untuk mempertahankan hubungan yang harmonis. Ternyata, Yohanes dan Yuni dalam berkomunikai saat terjadi konflik adalah dengan menggunakan cinta dan kasih. Sedangkan, pasangan informan II yaitu Yulius dan Ema. Saat mengalami konflik, cara mereka berkomunikasi tidak dengan cinta dan kasih, tetapi dengan kemarahan. Hal tersebut menyebabkan konflik semakin membesar dan akhirnya mereka bercerai.

\section{Kesimpulan}

Berdasarkan penelitian yang telah dilakukan, maka Peneliti mengemukakan beberapa kesimpulan bahwa dalam upaya mempertahankan hubungan yang harmonis, pasangan informan I (pasangan pernikahan beda agama yang langgeng) melakukan komunikasi antar pribadi dengan cara saling terbuka, mengkomunikasikan segala hal yang terjadi, saling menghormati dan saling mengingatkan termasuk dalam hal ibadah, menjaga komitmen untuk saling membahagiakan, saling memahami karakter dan keinginan pasangan, saling mengalah bila ada konflik dengan menekan ego masing-masing, dan mereka telah memberikan kebebasan kepada anak untuk memilih agama sesuai keinginan anak-anaknya. Jika ada konflik, pasangan informan I mencari solusi atau berkomunikasi dengan penuh cinta dan kasih, serta memilih waktu yang tepat untuk membicarakan konflik tersebut. selain itu, pasangan langgeng tersebut mempunyai prinsip yang selalu mereka pegang teguh "Sетиа agama mempunyai satu tujuan yang sama yaitu Tuhan." Hal tersebutlah yang membuat pernikahan pasangan informan I bertahan dan harmonis hingga saat ini, selama 28 tahun. Komunikasi antar pribadi yang efektif terbukti sangat penting dalam dalam mempertahankan hubungan yang harmonis dalam pernikahan beda agama.

Sedangkan, pasangan informan II (pasangan pernikahan beda agama yang 
telah bercerai) hanya kadang-kadang saja melakukan komunikasi antar pribadi. Hal tersebut menyebabkan konflik diantara mereka tidak terselesaikan. Selain itu, kurangnya keterbukaan diri dan kurangnya sikap saling menghormati, serta ego yang tinggi juga menjadi penyebab perceraian mereka. Sementara itu, hambatan atau konflik yang terjadi dalam pernikahan beda agama pasangan informan I (langgeng), dapat diatasi dengan komunikasi antar pribadi. Komunikasi antar pribadi yang dilakukan oleh pasangan informan I dapat mendorong adanya saling keterbukaan diri. Keterbukaan diri yang disertai sikap saling memahami dan mengalah dilakukan tersebut, ternyata dapat membantu menyelesaikan konflik yang terjadi dalam pernikahan mereka. Dengan begitu, hubungan yang harmonis dalam pernikahan beda agama pasangan informan I dapat tercapai.

\section{Daftar Pustaka}

Abdulkadir Muhammad. 2005. Ilmu Sosial Budaya Dasar. Bandung: PT.Citra Aditya Bakti
Deddy Mulyana. 2004. Ilmu Komunikasi: Suatu Pengantar. Bandung: PT. Remaja Rosdakarya.

Devito, Joseph A. 1997. Komunikasi Antar Manusia (Edisi 5). Jakarta: Professional Books.

Jalaluddin Rakhmat. 2001. Psikologi Komunikasi. Bandung: PT. Remaja Rosdakarya.

Littlejohn, S., \& Foss, K. 2009. Theories of Human Communication (Edisi 9). Jakarta: Salemba Humanika.

Nana Syaodih Sukmadinata. 2008. Metode Penelitian Pendidikan. Bandung: PT. Remaja Rosdakarya.

Sasongko Widarjono. 2007. "Kunci Perkawinan Bahagia." (online), (http://id.shvoong.com/humani ties/1653762-10-kunciperkawinan-bahagia/, diakses 2 Oktober 2012).

(http://en.wikipedia.org/wiki/kaphubungan-harmonis/ 9 Oktober 2012).

(http://komunikasiantarpribadi.org/20 10/10/jalinan-hubungan-kap/ 9 Oktober 2012). 